\title{
CERTIFICATION CRITERIA MATRIX FOR EXPERT RATING OF PROFESSIONAL SERVICES
}

\author{
Sarmite Jegere \\ University of Latvia, Latvia
}

\begin{abstract}
In the Latvian certification system of individuals, there is necessary to ensure appropriate process realization in the interests of public protection and government needs, which gets incorporated into the EU common structure. An assessment of the certification system and its institutional structure is done with the aim to develop proposals for the improvement of the Latvian certification system for reducing costs, while ensuring both high system efficiency and recipients services and the public interest. To achieve its goals, the research study provided a summary of the situation in Latvia, as well as in the neighbouring countries: Lithuania, Poland, Estonia and Finland. During the research study, there were used both the secondary and the primary sources of information. Primary research was carried out in Latvia and consisted of two parts: expert interviews and focus groups. The results of the research are guidance to the overall approach and the criteria by which to guide one in the future, for setting which professional service providers require a mandatory certification. A matrix was made in the process of the research, which helps to define a certified profession, taking into account the need to protect the public interest and the level of national involvement in the regulation of specific areas of professional services.
\end{abstract}

Keywords: certification, regulated and non- regulated professions, risks.

\section{Introduction}

In the Latvian certification system of individuals, there is necessary to ensure appropriate process realization in the interests of public protection and government needs, which gets incorporated into the EU common structure. The research study was done within the framework of a project "Support for the Implementation of Structural Reforms in the Government" administered by the State Chancellery.

There are regulated and non-regulated occupations. (On Regulated Professions and Recognition of Professional Qualifications; Article 1, Paragraph 12.). So, there can be separated two types of recognition of professional qualifications:

- "De jure" professional recognition of regulated professions. To be eligible to work in these occupations, the national legal acts (laws of the Republic of Latvia, the regulations of the Cabinet of Ministers or the ministerial normative documents) state that the person must have 
documents confirming the recognition of educational and professional qualifications.

- "De facto" recognition of professional non-regulated professions. In this case, the employer and / or professional organization is in need of information about the applicant's qualifications.

The object of the research study is both regulated and non-regulated occupations.

Regulated professions covered by the research study: security staff, architects, competent specialists of occupational health and safety, detectives, building, road and bridge construction professionals, surveyors, real estate appraisers. Non-regulated professions: dangerous machinery safety specialists (experts), energy auditors, accountants, geodesists, cartographers, real estate agents (brokers); land installers, tourist guides.

Aim of the research study. The assessment of the certification system and its institutional structure is done with the aim to develop proposals for the improvement of the Latvian certification system for reducing costs, while ensuring both high system efficiency and recipients services and the public interest.

Materials and methods. The research design of the evaluation was a mix of qualitative and quantitative methods for data acquisition and analysis. Within the framework of this evaluation, an analysis was done on certification and accreditation documents and secondary data, interviews with key stakeholder groups, as well as an analysis of the focus group and other Member States' successful experience.

Table 1 Research design of the evaluation (source: created by the author)

\begin{tabular}{|c|c|c|}
\hline \multicolumn{3}{|c|}{ Accordance, utility and professional competence evaluation of certification and accreditation } \\
\hline $\begin{array}{l}\text { 1. Secondary data } \\
\text { analysis } \\
75 \text { quantitative } \\
\text { indicators } \\
48 \text { document analysis } \\
\text { in Latvia }\end{array}$ & $\begin{array}{l}\text { 2. Interviews } \\
30 \text { structured } \\
\text { interviews } \\
15 \text { qualitative } \\
\text { indicators }\end{array}$ & $\begin{array}{l}\text { 3. Focus group and case analysis } \\
\text { - method of participation in the focus group } \\
\text { - } 4 \text { foreign experience analyses }\end{array}$ \\
\hline \multicolumn{3}{|c|}{ The purpose of the assessment } \\
\hline \multicolumn{2}{|c|}{$\begin{array}{l}\text { Objective } 1 \text { - To evaluate the accordance of } \\
\text { the compliance assessment system with the } \\
\text { protection of the legitimate interests of the } \\
\text { society } \\
\text { Objective } 2 \text { - Present proposals for its } \\
\text { maintenance or activities to increase the } \\
\text { efficiency of particular service areas or the } \\
\text { provision of separate services. }\end{array}$} & $\begin{array}{l}\text { Objective } 3 \text { - To develop recommendations for } \\
\text { improving the organization of certification and the } \\
\text { accreditation system in Latvia } \\
\text { Objective } 4 \text { - To develop proposals for common } \\
\text { criteria for its implementation or maintenance } \\
\text { Objective } 5 \text { - Create a universal matrix for } \\
\text { evaluation of certification necessity }\end{array}$ \\
\hline
\end{tabular}


The evaluation methodology consists of three successive stages of data collection and analysis: (1) analysis of secondary data; (2) interviews; (3) focus group and case analysis. These steps are subordinate to the evaluation objectives. The first two stages examined the accordance of the certification system, the quality and usefulness of implementation and management. However, at the third stage, there were developed proposals for improving the implementation of the certification system and a strategic discussion on its implementation.

At the first stage - the analysis of secondary data - documents related to the accreditation requirements for certification institutions and additional requirements, as well as the available statistical (quantitative) indicators, were collected and analysed. The primary goal of this phase was to collect and compile information for accomplishing the first three evaluation tasks, but the secondary goal - to contextualize the interview questions suggested in the evaluation according to the situation in Latvia. At the second phase, structured interviews were carried out with key group members involved in accreditation. At this stage, the information was supplemented to answer the questions of evaluation that were in line with the first two evaluation tasks.

At the third stage, a focus group and case analysis was carried out to make proposals for improving the programme based on the focus group and case analysis. Successful experience from other countries was viewed based on successful examples of activity implementation policy. Significant members involved in the programme were invited to take part in the focus group. Using participatory and creative methods, the focus group verified the key conclusions of the evaluation and made suggestions for improving the programme.

To achieve its goals, the research study provided a summary of the situation in Latvia, as well as in the neighbouring countries: Lithuania, Poland, Estonia and Finland. During the research study, there were used both the secondary and the primary sources of information. Previous research studies, databases and Internet resources, which can provide the necessary information about the certification principles, criteria, institutions, costs, etc., were used as secondary sources of information.

Primary research was carried out in Latvia and consisted of two parts: expert interviews and focus groups.

Primary investigation has obtained the arguments and facts about the system of certification in Latvia and possible improvements to increase the system functionality and reduce costs.

\section{Results}

As a result, there was summarized the information about institutions involved according to the evaluation system, duties and responsibilities of the 
accredited accordance evaluation institutions or representatives of the certified professions in each country analysed in this research. The Latvian system was compared with the certification systems of Estonia, Lithuania, Poland and Finland. The responsibility of certification in Latvia is carried out by "Standardization, Accreditation and Metrology Center" Ltd., which consists of three structural units - standardization, accreditation and metrology offices, which are the basis for the national quality assurance infrastructure. Accreditation is obligatory for those institutions that are determined by law or by the Cabinet of Ministers, but for non-regulated professions it is voluntary, i.e. the desire of the organization itself. Basically, the accreditation process in Latvia monitors how are evaluated such factors as: 1. Education; 2. Competence (academic and practical); 3. Experience; 4. Legal status; 5. Resources required for the provision of the service; 6 . In addition, the certification procedure carried out by the certifying authority is evaluated.

In Estonia, however, the certification of professions is carried out by the Estonian Qualifications Authority. There are, in total, 16 sectors or groups of professions that are monitored by the administration. Each sector is supervised by the sector council. The sector council appoints a certification organization, which participates in competition, organized by the council. The organization winning this competition earns the right to carry out certification for five years.

In Lithuania, the certification system is formed by the Lithuanian Qualifications Framework, which has different levels of qualification that characterizes the individual's level of competence. This framework is aligned with the European Qualifications Framework. There are 29 regulated professions in the Republic of Lithuania (compared with 91 in Latvia).

Almost all the professions studied are regulated in Poland. The only exception is competent specialists of work safety, which is an unregulated profession.

Each of these certification processes involves four sections. First of all, the monitoring institution, which in most cases is the ministry responsible for the field. Second, the institution that directly manages and organizes the certification process. Third, the law. Finally, the fourth phase is the target audience. As a target audience, there can be two - legal entities and individuals - and in most professions both exist, and not just one.

In Finland, the practice and knowledge of the profession can be gained in educational institutions, as well as in practice, through a six-month process at the workplace, during which the trainee acquires the skills necessary for the job market. For example, vocational secondary education is sufficient to qualify as a trainee or apprentice. You can then qualify for a higher secondary vocational qualification by completing a competency test. Similarly, adult education and training are based on norms regulated by a separate law. Students can then go to 
universities or polytechnics, which are more job-oriented. There are a number of regulated and unregulated professions in Finland. As regards regulated professions, there is a need for an appropriate level of education and a certain degree of qualification.

The analysis resulted in guidelines for optimal distribution of duties and responsibilities among state, private and public organizations. As the results of the research, there is provided guidance to the overall approach and the criteria by which to guide one in the future, for setting which professional service providers require a mandatory certification. There has been made a matrix, which helps to define a certified profession, taking into account the need to protect the public interest and the level of national involvement in the regulation of specific areas of professional services.

A risk analysis and assessment was carried out as the first step in the development of certification criteria. One can distinguish two probabilistic risk methods:

- The objective of the event is based on the given repetition frequency calculation;

- $\quad$ The subject is based on personal experience, an expert assessment consultant's opinion.

The certification system and the potential risk calculation are very difficult and often impossible. Therefore, this research study used a subjective method of using expert and consultant ratings. In total - 15 specialities were considered and 22 risks assessed. The lowest ratings for risks were: international risks; national, ecological and techno genic risks; technical and insurance risks. The most frequently encountered are: subjective; economic; tax and legal risks. Most risky professions: security specialists of dangerous equipment; people involved in construction of buildings, roads and bridges.

The potential risk to mitigate the impact of specific countermeasures is needed to provide the necessary protection. The most important mitigation measures identified in the analysis of international and Latvian research studies showed were as follows: education; insurance; work experience; monitoring and control.

The education criterion exists in all the Member States and applies to all professions which are certified. On various occasions, general or special education is used as criteria, as well as various educational levels: secondary and higher education. There are countries where the gained suitable education from the state view point is considered to be sufficient proof of professional ability to work in their chosen profession, as it is, for example, in Finland.

In spite of the right to work in the acquired speciality, also the non-regulated occupations often use the certification. In such cases, it works on a voluntary basis and is conducted by professional organizations such as associations or chambers 
of commerce. Often in such a situation, both the public and the local government bodies are involved in the process of monitoring the service quality. Local governments are involved in cases where the service is associated with a specific territory, as it is, for example, architects, real estate agents, tourist guides. Public bodies are significantly less involved in the supervision of service quality provided by unregulated professions, and it is done mostly through the consumer protection system.

Insurance is often used in risk protection. Liability insurance is a versatile tool that provides protection of the recipient, especially financial. In the profession assessment or certification/noncertification decision making, there are recommended several matrix options. They many have possible modifications. Based on the research study's analysis, you can change the determinants of risk indicators.

A simple risk assessment leads to conclusion that most professions are subjects of tax, economic, legal and political risks. Life and health risk doesn't matter in many professions, but the focus group participants believe that it is one of the main certification / non-certification criteria:

0 - risk is impossible;

3- there may be a risk;

1- risk cannot be excluded;

2- risk is probably half (50/50);

4- risk is very likely.

Education is a key component of anti-risk measures. Accreditation is only one of the possible ways for improvement, so this criterion is expanded as "requirements for education", where: 0 - no demands; 1 - primary education; 2 secondary education, courses; 3 - first level higher education; 4 - second level higher education, a master's degree.

The Law of Free Service Provision (Free Service Provision Law; paragraph 1 , point 10), points out 14 public protection measures to be carried out by its performers. Ratings are associated with the degree of realization of these measures: 0 - do not exercise; $1-1$ to 3 protective measures; 2 - 4 to 6 protective measures; 3 - 7 to 9 protective measures; $4-10$ to 14 protective measures.

One of the ways to improve the attitude towards work events is the use of a code of ethics. This is especially appreciated by the Western European countries, but Latvia it is included in paragraph 3, point 5 of the Law "On Regulated Professions and Recognition of Professional Qualifications" as an Additional Requirement for Regulated Professions. Evaluation: 0 - absent; 1 - has been prepared but not implemented; 2 - is in the association as advisable; 3 - is in the association as a mandatory requirement for all; 4 - is included as a requirement of the legislation. 
Table 2 Matrix (source: created by the author)

\begin{tabular}{|c|c|c|c|c|c|c|c|c|c|c|c|}
\hline \multirow{2}{*}{ 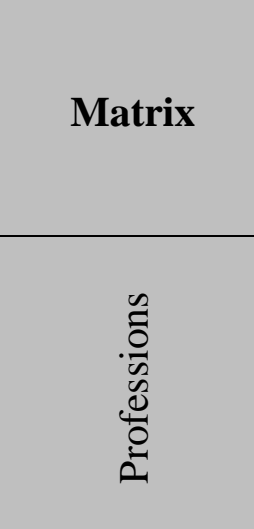 } & \multicolumn{4}{|c|}{ Risks } & \multirow{2}{*}{ 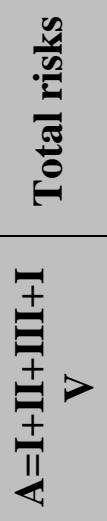 } & \multicolumn{4}{|c|}{ Anti-risk measures } & \multirow{2}{*}{ 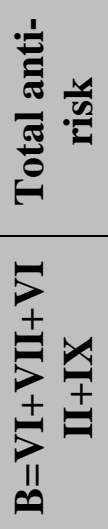 } & \multirow{2}{*}{ 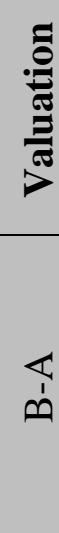 } \\
\hline & 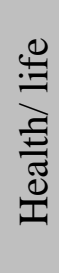 & 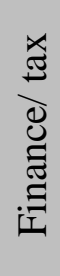 & 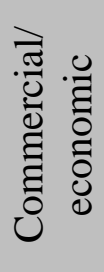 & 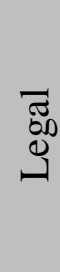 & & 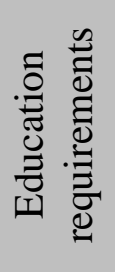 & 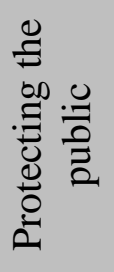 & 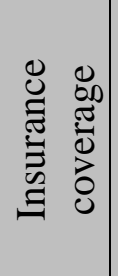 & 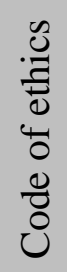 & & \\
\hline 0 & I & II & III & $\begin{array}{l}\mathrm{I} \\
\mathrm{V}\end{array}$ & $\mathbf{V}$ & VI & VII & VIII & IX & $\mathbf{X}$ & XI \\
\hline Architects & 3 & 4 & 4 & 2 & 13 & 4 & 0 & 0 & 0 & 4 & -9 \\
\hline Guards & 4 & 1 & 3 & 3 & 11 & 2 & 2 & 4 & 3 & 11 & 0 \\
\hline Geodesists & 1 & 2 & 2 & 2 & 7 & 4 & 0 & 0 & 0 & 4 & -3 \\
\hline $\begin{array}{l}\text { Dangerous } \\
\text { equipment } \\
\text { security } \\
\text { experts }\end{array}$ & 4 & 2 & 2 & 2 & 10 & 0 & 3 & 0 & 1 & 4 & -6 \\
\hline $\begin{array}{l}\text { Occupational } \\
\text { Health and } \\
\text { Safety } \\
\text { Specialists }\end{array}$ & 4 & 2 & 1 & 3 & 10 & 4 & 3 & 4 & 0 & 11 & +1 \\
\hline Detectives & 3 & 2 & 2 & 3 & 10 & 4 & 3 & 0 & 3 & 10 & 0 \\
\hline Accountants & 0 & 4 & 4 & 4 & 12 & 3 & 3 & 0 & 2 & 8 & -4 \\
\hline Surveyors & 2 & 2 & 2 & 3 & 9 & 4 & 0 & 0 & 0 & 4 & -5 \\
\hline Tourist guides & 1 & 1 & 1 & 0 & 3 & 3 & 2 & 0 & 0 & 5 & +2 \\
\hline
\end{tabular}

It is possible to expand the range of both risk and anti-risk measures. For example, for architects, the "impact in time" is a significant risk. It can be divided as " 0 - none, 1 - up to a month, 2 - to year, 3 - 1-5 years, 4 - more than 5 years". On the other hand, in the anti-risk measures, the matrix can be supplemented by the "State supervision" popular in Latvia and the "Municipal supervision" more used in comparable countries.

The matrix shows the calculation logic, however it is clear that a risk assessment is not and cannot be so simplified. Therefore, an accurate risk assessment follows this sequence and conditions: 
1.Matrix is added to a number of peer reviews, with the size and significance of the risk determination for each profession. For, example:

Table 3 Multiple expert assessment Matrix (source: created by the author)

\begin{tabular}{|c|c|c|c|c|c|c|c|c|c|c|}
\hline & \multicolumn{3}{|c|}{ Expert I } & \multicolumn{3}{c|}{ Expert II } & \multicolumn{2}{c|}{ Expert III } & Wei- \\
\hline $\begin{array}{c}\text { Profes- } \\
\text { sion }\end{array}$ & $\begin{array}{c}\text { Risk } \\
\text { amount }\end{array}$ & $\begin{array}{c}\text { Nota- } \\
\text { bility }\end{array}$ & $\begin{array}{c}\text { Wei- } \\
\text { ghted } \\
\text { value }\end{array}$ & $\begin{array}{c}\text { Risk } \\
\text { amount }\end{array}$ & $\begin{array}{c}\text { Nota- } \\
\text { bility }\end{array}$ & $\begin{array}{c}\text { Wei- } \\
\text { ghted } \\
\text { value }\end{array}$ & $\begin{array}{c}\text { Risk } \\
\text { amount }\end{array}$ & $\begin{array}{c}\text { Nota- } \\
\text { bility }\end{array}$ & $\begin{array}{c}\text { Wei- } \\
\text { ghted } \\
\text { value }\end{array}$ & $\begin{array}{c}\text { ghted } \\
\text { average }\end{array}$ \\
\hline
\end{tabular}

For the risk assessment according to probability (risk value) and the degree of effect (the importance), experts use the following values:

Table 4 Risk assessment probability and degree of effect (source: created by the author)

\begin{tabular}{|c|c|c|}
\hline Evaluation system & Risk probability & Risk effect \\
\hline 4 & The risk is very likely & Catastrophic \\
\hline 3 & Risk is possible & Critical \\
\hline 2 & The risk is probably half $50 / 50$ & Serious \\
\hline 1 & Risks cannot be excluded & Minor \\
\hline 0 & Risks cannot be & Minor \\
\hline
\end{tabular}

2. Qualitative and quantitative risk analysis and evaluation. This research study employs qualitative analysis, because, for quantitative analysis, it is necessary the assessment of occurred risk in terms of money. To use this exercise, it requires a lot of financial information that the author of this research study did not obtain.

2.1. Risk qualitative analysis.

It does not give an accurately measurable risk value, but allows you to set the priority risks (ranked in order of impact amount). It is based on the nominal or descriptive scales, which include the possible consequence analysis, viewing two dimensions - risk probability and risk consequences. (Working Environment Risk Assessment Guidelines, 2003) 


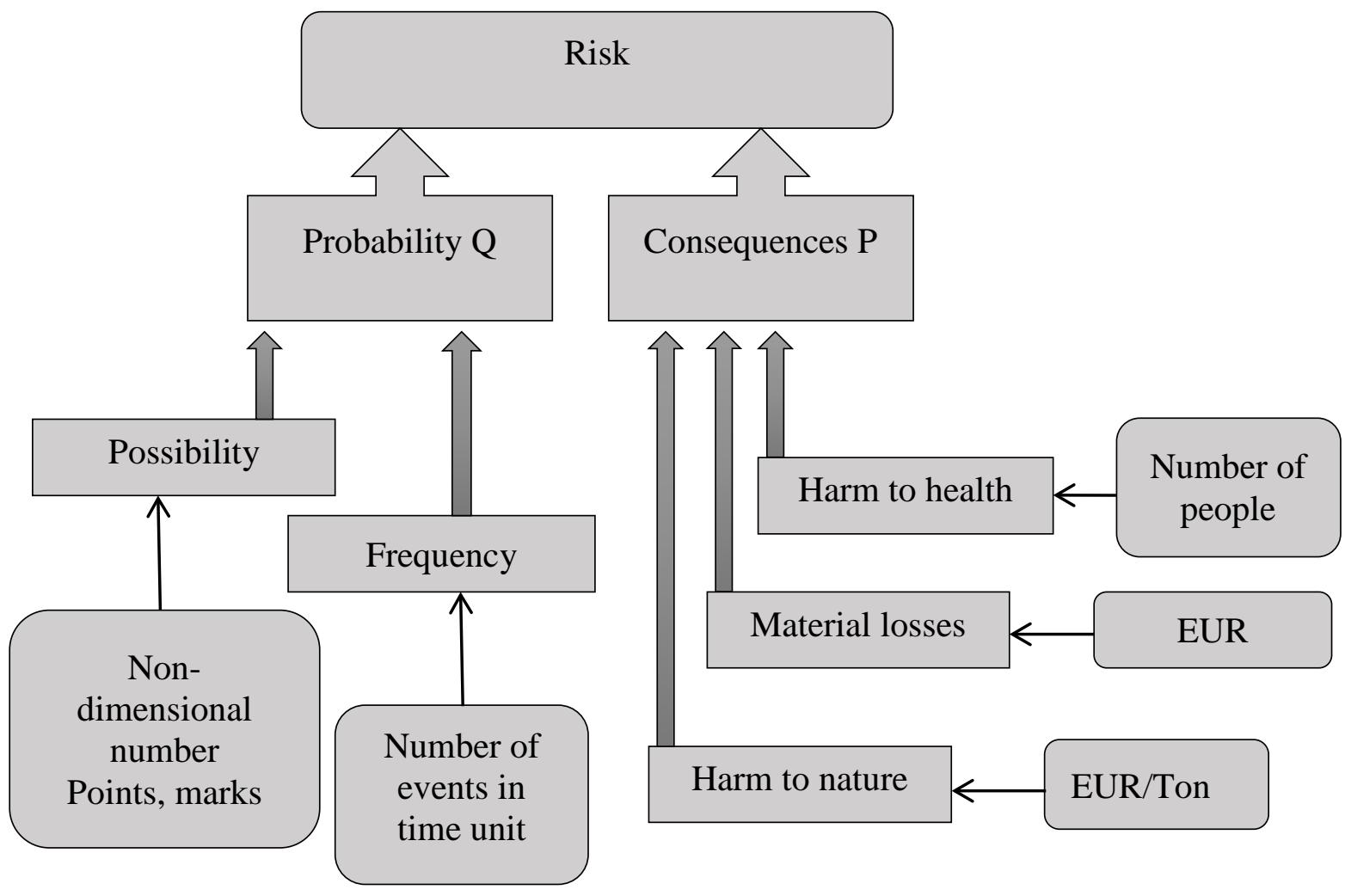

Fig.1. Components of risk assessment - probability and consequences

(Darba vides risku novērtēšanas vadlīnijas, 2003, 17)

1st variant.

Table 5 An example of a qualitative analysis of risk (Vellers, 2012)

\begin{tabular}{|l|c|c|c|c|c|}
\hline \multirow{2}{*}{ Probabilities } & \multicolumn{5}{|c|}{ Consequences } \\
\cline { 2 - 6 } & Insignificant & Little & Medium & Big & Catastrophic \\
\hline Almost sure & Medium & Medium & High & High & High \\
\hline Quite possible & Low & Medium & Medium & High & High \\
\hline Possible & Low & Medium & Medium & Medium & High \\
\hline Low possibility & Low & Low & Medium & Medium & High \\
\hline Rarely & Low & Low & Low & Medium & Medium \\
\hline
\end{tabular}

In Table 5, the interaction of probability and consequences can be traced, which is wider than the evaluation offered in Table 4. Multiplication of probabilities and consequences is the expected value of risk (or risk value). However, it is the average value i.e. if you run an activity several times, the risk can sometimes appear and sometimes not. Therefore, Table 5 was offered to the experts for the initial evaluation, the average results of which are shown in Table 
Jegere, 2018. Certification Criteria Matrix for Expert Rating of Professional Services

2nd variant.

Table 6 Risk Assessment Matrix (Melbourne University, 2003)

\begin{tabular}{|c|c|c|c|c|c|}
\hline \multirow{2}{*}{$\begin{array}{l}\text { Identify } \\
\text { the danger }\end{array}$} & \multicolumn{3}{|c|}{ Risk Assessment } & \multirow{2}{*}{$\begin{array}{c}\text { Rating } \\
(\mathrm{R}=\mathrm{ExVxS})\end{array}$} & \multirow[b]{2}{*}{ Risk level } \\
\hline & $\begin{array}{c}\text { Exposition } \\
\text { (E) }\end{array}$ & $\begin{array}{c}\text { Probability } \\
\text { (V) }\end{array}$ & $\begin{array}{c}\text { Consequences } \\
\text { (S) }\end{array}$ & & \\
\hline & & & & & \\
\hline
\end{tabular}

This method, in practical application, forms the following risk assessment (Table 7), where: $\mathrm{K}$ - catastrophic or extreme risk when shares are needed immediately; L - high risk, intervention of the work protection specialists is needed and a plan of activities is required; $\mathrm{V}$ - average risk, security measures must be specified, priorities must be set; $\mathrm{M}$ - low risk, order is necessary in work management and work protection. The method we recommend to regulated professions for their risk assessment.

Table 7 Definitions of Risk Assessment Matrix (Melbourne University, 2003)

\begin{tabular}{|lr|lr|lr|l|}
\hline \multicolumn{2}{|c|}{ Exposition (E) } & \multicolumn{2}{c|}{ Probability (V) } & \multicolumn{2}{c|}{ Consequences (S) } & \multicolumn{2}{c|}{ R } \\
\hline Continuous & 10 & No doubt & 1,0 & Catastrophic & 20 & K > 20 \\
Often & 6 & Possible & 0,6 & Big & 10 & $\mathbf{L}>\mathbf{1 0}$ \\
Sometime & 3 & Probable & 0,3 & Medium & 5 & V 3 - 10 \\
Rarely & 2 & Small & 0,1 & Small & 2 & $\mathbf{M ~ 3 ~}$ \\
Very rare & 1 & Very small & 0,05 & Insignificant & 1 & \\
\hline
\end{tabular}

The risk management model (required activities) can be applied for qualitative risk evaluation on a 5 point scale. The model was developed in Finland at the Tampere University of Technology and is often used to assess the work environment risks for companies with relatively simple technological processes of production.

3rd variant.

Table 8 Risk assessment matrix II (Melbourne University, 2003)

\begin{tabular}{|c|c|c|c|}
\hline \multirow{2}{*}{$\begin{array}{c}\text { Possibility of a } \\
\text { risk }\end{array}$} & Low danger & Danger & High danger \\
\cline { 2 - 4 } Not possible & $\begin{array}{c}\text { Insignificant risk } \\
\text { I }\end{array}$ & $\begin{array}{c}\text { Acceptable risk } \\
\text { II }\end{array}$ & $\begin{array}{c}\text { Tolerable risk } \\
\text { III }\end{array}$ \\
\hline \multirow{2}{*}{ Low possibility } & $\begin{array}{c}\text { Acceptable risk } \\
\text { II }\end{array}$ & $\begin{array}{c}\text { Tolerable risk } \\
\text { III }\end{array}$ & $\begin{array}{c}\text { Insignificant risk } \\
\text { IV }\end{array}$ \\
\hline \multirow{2}{*}{ Possible } & Tolerable risk & $\begin{array}{c}\text { Insignificant risk } \\
\text { III }\end{array}$ & $\begin{array}{c}\text { Unacceptable risk } \\
\text { V }\end{array}$ \\
\hline
\end{tabular}


4th variant.

R. Simon, a Professor of Business Administration at Harvard Business School, offers an interesting approach to long-term risk assessment (Simons, 1999). The method is named the Harvard business risk calculator. The calculator indicates weaknesses which can contribute to the increasing risks and points them out for the management of the organization. The calculator is not a precise methodology, and its results only indicate the direction.

The Harvard Business Risk Calculator covers three internal weak points: growth; culture; information administration.

Table 9 Harvard Business Risk Calculator (Vellers, 2012)

\begin{tabular}{|c|c|c|c|}
\hline \multicolumn{5}{|c|}{ Growth } \\
\hline $\begin{array}{c}\text { Pressure on work } \\
\text { execution }\end{array}$ & Growth rate & $\begin{array}{c}\text { Lack of leadership } \\
\text { experience }\end{array}$ & \\
\hline 12345 & 12345 & 12345 & Result (sum) \\
\hline \multicolumn{4}{|c|}{ Culture } \\
\hline $\begin{array}{c}\text { Reward for } \\
\text { entrepreneur ideas }\end{array}$ & $\begin{array}{c}\text { Leadership resistance to } \\
\text { bad news }\end{array}$ & Internal competition & \\
\hline 12345 & 12345 & 12345 & Result (sum) \\
\hline \multicolumn{5}{|c|}{ Information administration } & \\
\hline $\begin{array}{c}\text { Transaction } \\
\text { complexity and } \\
\text { speed }\end{array}$ & $\begin{array}{c}\text { Disadvantages in } \\
\text { diagnostic execution } \\
\text { assessments }\end{array}$ & $\begin{array}{c}\text { Decentralized } \\
\text { decision-making level }\end{array}$ & \\
\hline 12345 & 12345 & 12345 & Result (sum) \\
\hline
\end{tabular}

Harvard Business Risk Calculator: 9-20 points: a safe zone; 21-34 points: a precautionary zone; 35-45 points: a dangerous zone.

2.2. Risk quantitative analysis. Quantitative risk assessment is based on mathematical methods, using the principles of probability theory, algorithms, empirical coefficients, functions, methods of analysis, as well as a variety of software programs. Risk quantification is the assessment of the risk event occurrence in terms of money. To use this evaluation, it requires extensive financial information that the author of this research study was not available to acquire.

3. The anti-risk measures. It should be noted that risk cannot be transferred, but can be divided.

Dividing ways: insurance; outsourcing; joint venture; franchise.

Possible additions are carried out to risk assessment analysis, but in the proposed Matrix, the second section - anti-risk measures are important. It should be noted that the risk cannot be transferred, but can be divided.

Insurance offered in the Matrix. 
There is no standard list of risks that are worth to insure because the priority risks vary depending on the company's activities and specifics. Insurance is often a cost-effective risk management method, as it provides protection against the risk of a price that is lower than the risk value.

Typical risks to be insured are: threats to property (fire, storm, vandalism, etc.); loss of income (strike, fraud, etc.); accidents; environmental pollution; professional responsibility.

Matrix offered insurance, which provides for three types of insurance: Accident, Environmental Pollution, Professional Liability. However, a further analysis is required here, where the main aim is for the insurance to be lower than the price of risk. Otherwise, the insurance will not have an expected effect.

There is also carried out an initial redistribution of risk between the public and private partners. In the case of the research study, it may also occur between the state, municipalities and the private partner. The Latvian accreditation and certification system provides public and private responsibility in risk management. Only in one case (tour guides), it is entrusted to the municipalities. Redistribution of risks is also possible in this aspect.

\section{Conclusions}

Recommendations are developed to assess risks and compare the experience of different countries.

- It is advisable not to regulate some of the currently regulated professions (architects, building, road and bridge construction professionals, real estate appraisers).

- It is desirable to reinforce the role of education in the evaluation of professions (architects, dangerous machine safety specialists, energy auditors, building, road and bridge construction professionals, geodesists, land installers, surveyors, accountants).

- $\quad$ For certain professions (security staff, accountants, tourist guides) the process of certification can be divided into degrees, levels.

- For professions such as architects, building, road and bridge construction professionals and real estate agents (brokers), a mandatory requirement for civil liability insurance cover has to be introduced.

A country comparison has revealed differences and similarities and good examples that could be taken over:

The security certification systems are similar in all the countries analysed in the research study. However, it is necessary to differentiate security personnel according to the degree of danger and the necessary knowledge. The existing certification system in Latvia is suitable for security personnel who uses firearms. However, security guards are also, for example, museum hall supervisors who do 
not need a full security training programme. Therefore, it is advisable to take over the certification system for security staff in Estonia and divide it into several levels, setting educational requirements for each level according to the range of work duties.

In general, the certification system for architects works in most of the analysed countries. The used systems are very diverse - from strictly stateregulated (Poland) to completely liberal (Finland), where the architect's diploma is also regarded as proof of competence and skills. Currently, Latvia is operating a system, within the framework of which the process of certification is held by the Latvian Association of Architects. However, a number of weaknesses have been identified in this system. The main problem is that the certifying and supervising institution is one and the same. The solution would be the involvement of a third party, which could be a state institution controlled by the Ministry of Economics that supervises the construction sector. A similar situation is also with the certification of other construction specialists.

In Estonia, the certification of dangerous equipment security specialists is carried out by a public organization, but in Poland - a state organization. In Lithuania, the activities of this profession are not regulated, while in Finland and Latvia, the employer is responsible for work safety when personnel is handling dangerous equipment. In all the countries analysed, except for Latvia, one of the main criteria for professional activity in this field is education, indicating that it have to be the higher. In Finnish companies, most of the employees have a master's degree and a doctor's degree, the lowest acceptable level of education for working with dangerous equipment is the bachelor's degree in the particular specialty.

Lithuania and Poland do not provide for the certification of competent specialists in labour protection. There is no such a procedure in Finland, but special attention is paid to the employer's responsibility. In Estonia, only health professionals are certified. Latvia is the only one of the countries that are analysed in this research study, where there is certification and accreditation of competent specialists in labour protection.

In the analysed countries, there is no unified approach to detective certification. In Estonia and Lithuania, this profession is not regulated by law and certification is not required. In Finland, the most important aspect is education, and only in Poland it is necessary to take a special examination to become a detective. The Detective Activity Law was adopted in Latvia, but only documents are evaluated in the process of certification.

In Estonia, Latvia and Lithuania, the certification of accountants is carried out by public organizations, in Poland - by a state institution, in Finland - by the Chamber of Commerce. In all the countries of this research study, accountants are 
required to have a certain level of education. As the basis for the change, the Estonian system is recommended, where accountants are divided into 6 levels.

In Estonia, Lithuania and Poland, the profession of tourist guides is regulated and certification requires obtaining certain education and a test of knowledge. In Finland, this profession is not regulated. Several studies have been devoted to the profession of tourist guides in Latvia and its certification problems. Compared with the other countries analysed in the research study, Latvia has chosen an unconventional way - the issue of certification of tourist guides is entrusted to the municipality. The recommendation is to take over the most significant experience from Lithuania and Estonia. In Lithuania, tourist guides have three categories. In Estonia, tourist guides are divided into 10 levels. In Lithuania, the government, but it can also be the municipality, approves a list of museums and cultural objects, in which only state-licensed guides may work. Financially, the certification process is supported by the Tourism Fund.

\section{References}

Brīvas pakalpojumu sniegšanas likums; 1. pants, 10. punkts. Latvijas Republikas likums.

Pieņemts Latvijas Republikas Saeimā 31.03.2010.; stājies spēkā 04.05.2010.; ar grozījumiem, kas stājās spēkā 18.06.2013. Latvijas Vèstnesis, 20.04.2010., Nr. 62 (4254). Darba vides risku novērtēšanas vadlīnijas (2003). Rīga: Labklājības ministrija.

Par reglamentētajām profesijām un profesionālās kvalifikācijas atzīšanu; 1. pants, 12. punkts.; 3. pants, 5. Punkts. Latvijas Republikas likums. Pieṇemts Latvijas Republikas Saeimā 20.06.2001.; stājies spēkā 20.07.2001. Latvijas Vēstnesis, 06.07.2001., 105 (2492). “Zinotājs”, 15, 09.08.2001.

Simons, R. (1999). How Risky Is Your Company? Harvard Business Review 77, no. 1.

Vellers, A. (2012). Risku vadība. Pieejams http://www.kurzemesregions.lv/userfiles/files/ 1337169143_Risku\%20vadiba.pdf 